\title{
Microstructure, Mechanical and Corrosion Properties of Extruded Milled Magnesium Powder
}

\author{
Drahomír Dvorskýn ${ }^{1,2}$, Jiř́ Kubásek ${ }^{1,2}$, Dalibor Vojtěch ${ }^{1}$ \\ ${ }^{1}$ University of Chemistry and Technology Prague, Faculty of Chemical Technology, Department of Metals and \\ Corrosion Engineering, Technická 516628 Praha 6 - Dejvice, Czech Republic., E.mail: dvorskyd@vscht.cz \\ 2Institute of Physics, Czech Academy of Science, Prague, Na Slovance 1999/2 18221 Praha 8 Czech Republic
}

Magnesium materials are interesting for application in medicine as biodegradable implants. There is an effort to improve mechanical and corrosion properties for this application. Powder metallurgy seems to be a progressive method suitable for improving those demanded properties. Therefore, this paper deals with the preparation of pure $\mathrm{Mg}$ by extrusion of milled powder. The milling process should lead to better homogeneity of microstructure and the disturbing of the oxide layer on the powder particles. Also, the input deformation energy in the milled powder should affect the deformation and recrystallization process during extrusion. In this paper, the influence of extrusion temperature on microstructure, mechanical, and corrosion properties is evaluated. Higher extrusion temperature leads to the larger deformed grains in the extrusion direction and higher tensile strengths. On the other hand, the plasticity and compressive yield strengths are reduced with higher extrusion temperatures. Corrosion properties are negatively affected by the iron inclusions incorporated in the structure during milling. Otherwise, corrosion resistance decreases with increasing extrusion temperature due to the grain size.

Keywords: Magnesium, extrusion, mechanical properties, corrosion, powder metallurgy.

\section{Introduction}

Lightweight materials such as magnesium are suitable for application in the automotive and aviation industry. There are high demands on the mechanical properties of such materials [1,2]. Another utilization of $\mathrm{Mg}$ is in the field of medicine where it serves as biodegradable implants. $\mathrm{Mg}$ is a suitable element for such applications due to its good biocompatibility and relatively good mechanical properties together with the ability of degradation in organisms without the creation of toxic corrosion products. Similar properties of $\mathrm{Mg}$ with the bone tissue result in the absence of the problem known as stress shielding effect which is common for materials that have far higher Young's modulus than bone tissue [3, 4]. The disadvantage of magnesium for such an application is its high corrosion rate which is associated with hydrogen release and the rise of $\mathrm{pH}$ near the implant. This might lead to the complications with healing process. Therefore, magnesium is usually alloyed for the improvement of mechanical and corrosion properties. Nevertheless, alloying elements have to be carefully chosen in order not to deteriorate biocompatibility.

From the biocompatibility point of view, it is better to use pure $\mathrm{Mg}$. High purity $\mathrm{Mg}$ is characterised with good corrosion resistance as there is an absence of galvanic corrosion. Otherwise, pure $\mathrm{Mg}$ alloys with common purity are sensitive for impurities such as $\mathrm{Fe}$, $\mathrm{Ni}, \mathrm{Cu}$, and Co. Dangerous impurities have to be held beneath certain limits in order to prevent excessive localised galvanic corrosion $[5,6]$.

Mechanical and corrosion properties of pure $\mathrm{Mg}$ might be improved by processing methods. Powder metallurgy is said to lead to the generally superior properties of most alloys. Also, thermomechanical processing and associated grain refinement exert improved properties $[7,8]$. Powder metallurgy is a wide subject that allows a lot of possible modifications of powder even before compactization. Powder might be heat-treated, chemically treated, or milled. Milling of the powder is based on the input of plastic deformation to the material. As a result, a powder might be finer and original grains are severely deformed. Although, the heat created during milling might result in partial dynamic recrystallization for materials with low recrystallization temperature such as $\mathrm{Zn}$. Deformation which is put in the material during milling has an impact on the recrystallization processes during compactization [9]. The final structure should be very finegrained.

One of the best methods of powder compactization is extrusion [10]. During extrusion, a green compact of the material is passed through a hole with a lower diameter, and the material is, therefore, severely deformed. Extrusion of magnesium has to be done at elevated temperatures due to the low amount of slipping planes of $\mathrm{Mg}$ at room temperature. At elevated temperatures, new slipping planes can be activated and makes the deformation of $\mathrm{Mg}$ possible. The extrusion 
temperature is an important factor which has also a great effect on the final properties of the material. Magnesium alloys are also known to form a typical basal texture after deformation. Such texture has a great effect on the anisotropy of mechanical properties due to the connection between grain orientation and twinning [11]. Milling of the powder before extrusion could lead to the suppression of the texture after extrusion [12].

Therefore, this work is aimed at the preparation of pure $\mathrm{Mg}$ by extrusion of milled powder at different extrusion temperatures. The impact of extrusion temperature on the microstructure, mechanical, and corrosion properties is investigated.

\section{Materials and methods}

\subsection{Sample preparation}

Magnesium commercial atomized powder (30 g) with impurities measured by ICP-MS (Elan DRC-e) (90 ppm Fe, 10 ppm Cu, 20 ppm Ni) was milled in a steel planetary ball mill for 4 hours with the speed of 400 RPM. The weight ratio between the powder and the balls was 1:19. Milled powder was pressed with a pressure of $255 \mathrm{MPa}$ on LabTest 5.250SP1-VM at room temperature for $5 \mathrm{~min}$. Magnesium green compacts were inserted into extrusion form and they were left for $10 \mathrm{~min}$ to heat up on the desired extrusion temperature. Subsequently, samples were extruded at $200{ }^{\circ} \mathrm{C}, 300{ }^{\circ} \mathrm{C}, 400{ }^{\circ} \mathrm{C}$, and $500{ }^{\circ} \mathrm{C}$ with extrusion ratio 10 and extrusion rate $5 \mathrm{~mm} / \mathrm{min}$. The final rods have a diameter of $6 \mathrm{~mm}$ and a length of $150 \mathrm{~mm}$.

\subsection{Microstructure}

Tab. 1 Composition of SBF [mmol/l].

\begin{tabular}{ccccccccc}
\hline Ions & $\mathbf{N a}^{+}$ & $\mathbf{K}^{+}$ & $\mathbf{M g}^{2+}$ & $\mathbf{C a}^{2+}$ & $\mathbf{C l}^{-}$ & $\mathbf{H C O}^{3-}$ & $\mathbf{H P O}_{4}{ }^{2-}$ & $\mathbf{S O}_{4}{ }^{2-}$ \\
\hline SBF & 142.0 & 5.0 & 1.5 & 2.5 & 147.8 & 4.2 & 1.0 & 0.5 \\
\hline
\end{tabular}

\section{Results and discussion}

\subsection{Microstructure}

Microstructures of extruded milled Mg powders at different temperatures are shown in Fig.1. One can see that in each material there are up to $5 \mu \mathrm{m}$ large iron inclusions (white bright spots), which were incorporated to the $\mathrm{Mg}$ matrix during milling from the milling balls and milling container. Inclusions will have probably slightly deteriorating effects on the mechanical properties and it will strongly affect corrosion properties [13]. The main difference in the microstructure of samples lies in the different grain sizes. The average thickness of the grain measured by image analysis was $1.3 \pm 0.4 \mu \mathrm{m}, 2.0 \pm 0.6 \mu \mathrm{m}, 9 \pm 6 \mu \mathrm{m}$, and $26 \pm 13 \mu \mathrm{m}$ for material extruded at $200{ }^{\circ} \mathrm{C}, 300{ }^{\circ} \mathrm{C}, 400{ }^{\circ} \mathrm{C}$, and $500{ }^{\circ} \mathrm{C}$ respectively. While the average length was 3.0 $\pm 1.3 \mu \mathrm{m}, 16 \pm 7 \mu \mathrm{m}, 192 \pm 75 \mu \mathrm{m}$, and $208 \pm 74 \mu \mathrm{m}$
The microstructure was characterised by scanning electron microscopy (SEM - Tescan VEGA3) equipped with energy dispersion spectrometry (EDS, AZtec). Samples were ground on $\mathrm{SiC}$ grinding papers (P80-P2500) and polished on diamond paste D3, D2, and D0.7. The final polishing was done on Etosil E. The grain size was measured by image analysis of 6 images by ImageJ software.

\subsection{Mechanical properties}

Compressive and tensile tests were performed on LabTest 5.250SP1-VM at room temperature. The specimens for compressive tests were cylindrical with $5 \mathrm{~mm}$ in diameter and $7 \mathrm{~mm}$ high. The strain rate of $0.001 \mathrm{~s}^{-1}$ was used. Basic mechanical data (compressive yield strength - CYS, ultimate compressive strength UTS) were evaluated. Tensile properties were measured on the cylindrical samples with a diameter of 3.5 $\mathrm{mm}$ in the narrowed area and $25 \mathrm{~mm}$ long. Basic mechanical data (tensile yield strength - TYS, ultimate tensile strength - UTS, and total elongation - A) were evaluated.

\subsection{Immersion test}

Immersion tests were performed in simulated body fluid (SBF) at $37^{\circ} \mathrm{C}$ for 14 days. The composition of SBF is in the Tab. 1. The ratio of solution volume to the surface area was $100 \mathrm{ml} \cdot \mathrm{cm}^{-2}$. After 14 days, samples were removed from the immersion solution and were rinsed in distilled water and dried. The corrosion products were removed by the solution of $200 \mathrm{~g} \cdot \mathrm{l}^{-1}$ $\mathrm{CrO}_{3}, 10 \mathrm{~g} \cdot \mathrm{l}^{-1} \mathrm{AgNO}_{3}, 20 \mathrm{~g} \cdot \mathrm{l}^{-1} \mathrm{Ba}\left(\mathrm{NO}_{3}\right)_{2}$ at room temperature. Samples were then dried and weighed. The corrosion rate was calculated from weight changes. for extrusion at $200{ }^{\circ} \mathrm{C}, 300{ }^{\circ} \mathrm{C}, 400{ }^{\circ} \mathrm{C}$, and $500{ }^{\circ} \mathrm{C}$ respectively. The grains were, therefore, prolonged in the direction of extrusion in all cases. The average grain size of the samples extruded at lower temperatures was smaller compared to the extruded $\mathrm{Mg}$ powder without milling $[14,15]$.

Samples extruded at $400{ }^{\circ} \mathrm{C}$ and $500{ }^{\circ} \mathrm{C}$ were characterised by large prolonged grains in the extrusion direction. This might be associated with grain growth which could occur even before extrusion. Deformation energy which was put into the powder during milling and high temperature could cause rapid grain growth during heating up of the green compact [9]. Those large grains were subsequently extruded and therefore, they are prolonged and probably contain residual stresses. Also, high extrusion temperature enabled better deformation as new slipping systems of the HCP structure were activated [16]. Nevertheless, there are also very fine recrystallized grains usually on the 
edges of the large grains. Materials extruded at $200{ }^{\circ} \mathrm{C}$ and $300{ }^{\circ} \mathrm{C}$ were characterised by much finer microstructure. Both temperatures are above the recrystallization temperature of $\mathrm{Mg}$, therefore, the recrystallization of green compact before extrusion could also occur. However, the stimulus energy was probably not that high because of lower temperature, therefore, the structure is much finer. Also, the extrusion temperature was too low for the activation of certain slipping systems and therefore, there was only a limited amount of prolonged deformed grains [16]. There is however a slight difference in microstructure between samples extruded at $200{ }^{\circ} \mathrm{C}$ and $300^{\circ} \mathrm{C}$. The microstructure of the sample extruded at $300^{\circ} \mathrm{C}$ is more homogeneous than the sample extruded at $200{ }^{\circ} \mathrm{C}$. This might be connected with the activation of the slipping planes and better recrystallization before extrusion for the sample extruded at $300{ }^{\circ} \mathrm{C}$. Extrusion temperature of $200{ }^{\circ} \mathrm{C}$ is below the ductile transition temperature $\left(225-250^{\circ} \mathrm{C}\right)$ which is necessary for the activation of $\langle c+a\rangle$ pyramidal slip, therefore, only low temperature dynamic recrystallization (LTDRX) occurs [16]. Limited amount of slipping planes and limited stimulus energy for recrystallization leads to the predominant effect of hardening mechanisms during extrusion. Extrusion temperature of $300{ }^{\circ} \mathrm{C}$ is probably close to an equilibrium where hardening and softening processes are in balance as will be discussed later.

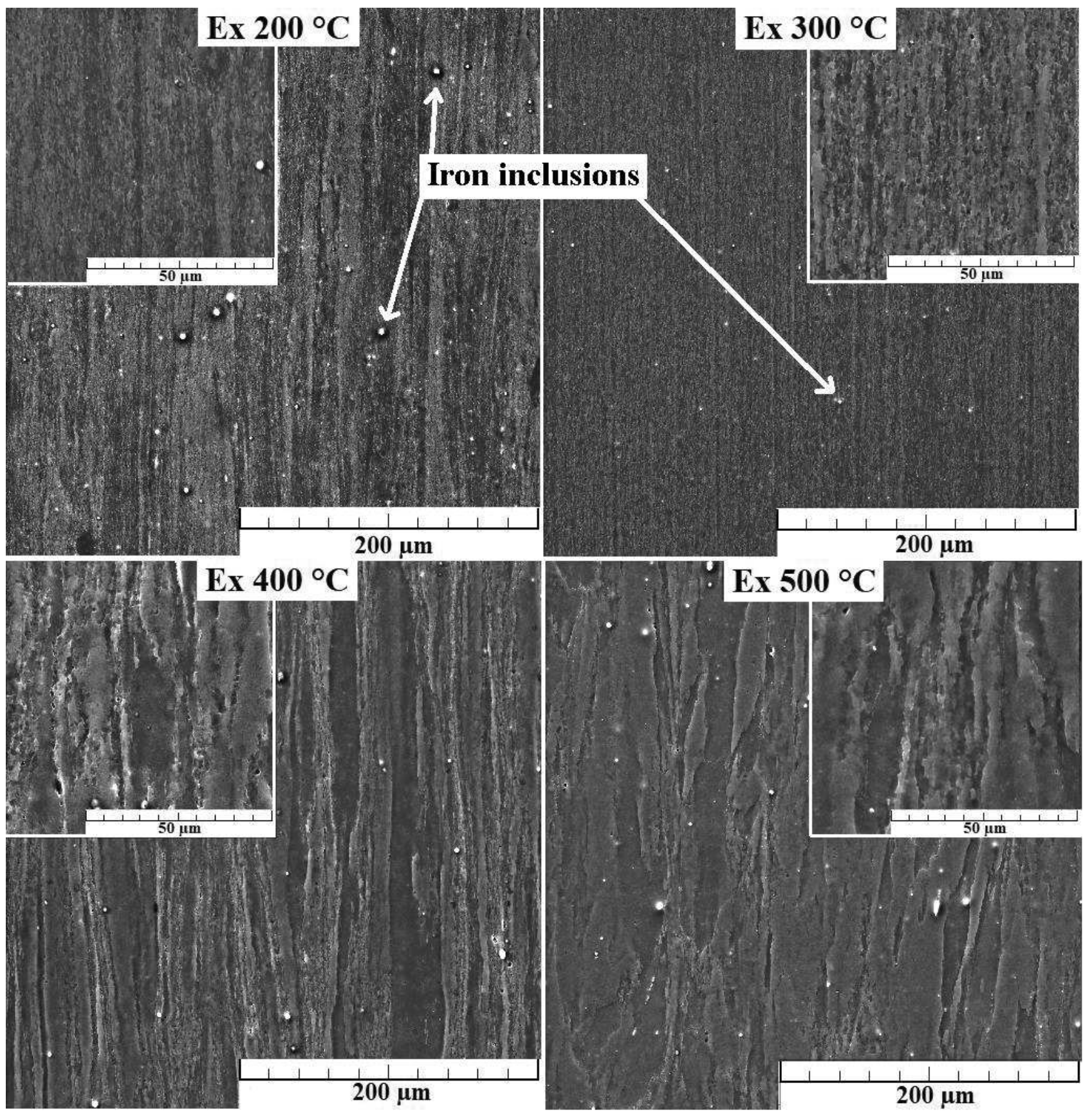

Fig. 1 The microstructure (SEM) of milled Mg powder extruded at $200^{\circ} \mathrm{C}, 300^{\circ} \mathrm{C}, 400^{\circ} \mathrm{C}$, and $500^{\circ} \mathrm{C}$. 


\subsection{Mechanical properties}

Representative compressive (solid line), tensile (dashed line), and extrusion (dash-point line) curves of the prepared materials are summarized in Fig.2. Extrusion curves of samples extruded at $400{ }^{\circ} \mathrm{C}$ and 500 ${ }^{\circ} \mathrm{C}$ have a similar shape. There is only a different onset force needed for the start of the extrusion which is associated with larger grains which were probably created during heating up of the green compact and higher extrusion temperature which activates new slipping systems and enables easier deformation [16]. After reaching the force needed for the initiation of the extrusion, the force is descending. This is associated with high temperature as softening mechanisms prevail over hardening. The situation is different for materials extruded at $200{ }^{\circ} \mathrm{C}$ and $300{ }^{\circ} \mathrm{C}$. Extrusion temperature of $300^{\circ} \mathrm{C}$ is characterised with an almost constant force of extrusion, which might mean that the softening and hardening mechanisms are at equilibrium. On the other hand, extrusion temperature of $200{ }^{\circ} \mathrm{C}$ has only ascending course of the curve, which means that hardening mechanisms prevail over softening due to the low temperature.

One can see, that the tensile yield strength (TYS) and ultimate tensile yield strength (UTS) are higher with higher extrusion temperature. On the other hand, the plasticity is highly deteriorated with higher extrusion temperature. This is associated with grain size, grain orientation, and residual stresses from the milling and extrusion process. The grain sizes of samples extruded at higher temperatures are larger and according to the Hall-Petch relation, the TYS should be lower. In this case, there could be texture and residual stress in the deformed stretched grains. As a consequence of texture and residual stress, the TYS and UTS are improved at the cost of lower plasticity. In this case, the orientation of grains is unfavourable for the twinning mechanism and, therefore, the deformation is primarily provided by a slip mechanism that requires more energy than the twinning mechanism. Contrary, the twinning mechanism occurred during compressive testing [17-19]. Such behaviour could be observed on compressive curves (solid line) of the samples extruded at 400 and $500^{\circ} \mathrm{C}$. The twinning occurs after reaching the compressive yield strength (CYS) and resulting in the hardening mechanism of the newly formed twins. The twinning is also amplified by larger grains. This hardening was slightly visible for the sample extruded at $300^{\circ} \mathrm{C}$ and was missing for the sample extruded at $200{ }^{\circ} \mathrm{C}$. This is associated with finer grains and the lack of deformed prolonged grains with a specific texture that would cause the twinning. Moreover, TYS of products extruded at 200 ${ }^{\circ} \mathrm{C}$ and $300{ }^{\circ} \mathrm{C}$ are lower compared to the CYS, which is common for most of the materials as possible defects have a greater impact on tensile properties. Therefore, there is no observed anisotropy of mechanical properties caused by the texture.

Mechanical properties of prepared materials were superior compared to extruded pure $\mathrm{Mg}$ prepared by conventional casting with subsequent extrusion (TYS $=106 \mathrm{MPa}, \mathrm{UTS}=178 \mathrm{MPa}, \mathrm{A}=10 \%$ - measured by Lei et al.[20]; TYS = $108 \mathrm{MPa}$, UTS = $173 \mathrm{MPa}$, $\mathrm{A}=6.7 \%, \mathrm{CYS}=120 \mathrm{MPa}, \mathrm{UCS}=190 \mathrm{MPa}-$ measured by Kubasek et al. [21]) probably due to the smaller grains size. Milling of the powder prior to extrusion provides comparable tensile properties as the powder metallurgy products (TYS $=232 \mathrm{MPa}, \mathrm{UTS}=$ $259 \mathrm{MPa}, \mathrm{A}=4.3 \%$ - measured by Peréz et al. [15]; TYS $=235 \mathrm{MPa}$, UTS $=273 \mathrm{MPa}, \mathrm{A}=6.8 \%$ - measured by Cavojsky et al. [14]). Nevertheless, those authors only measured tensile properties, and therefore, the effect of texture on the anisotropy of the mechanical properties cannot be discussed.
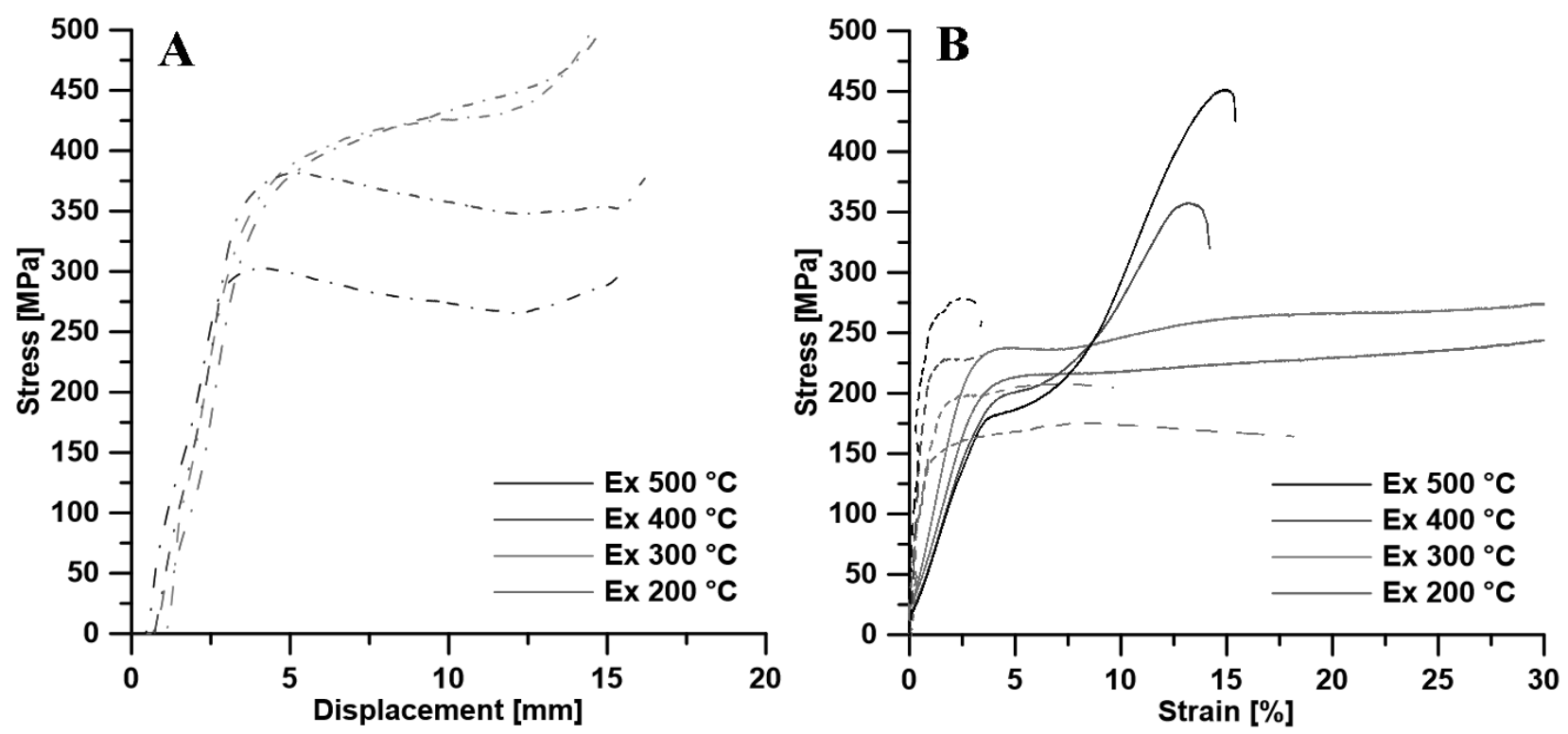

Fig. 2 A) Extrusion curves (dash-point line), B) Compressive (solid line) and tensile (dash line) of prepared materials. 


\subsection{Corrosion properties}

Corrosion properties were measured in the SBF at $37{ }^{\circ} \mathrm{C}$ for 14 days and the final corrosion rates after removal of corrosion products are summarized in Tab.1. One can see that the corrosion rate of all products is relatively high due to the presence of Fe from ball planetary mill. Nevertheless, the values are still lower compared to extruded gas-atomized powder.

Tab.1 Corrosion rate in simulated body fluid

$\begin{array}{rr}\mathbf{E x} 200{ }^{\circ} \mathbf{C} \\ \mathrm{v}_{\text {cor }}\left[\mathrm{mm} \cdot \mathrm{a}^{-1}\right] & 1.9 \pm 0.1\end{array}$

\section{Conclusion}

Rods of pure $\mathrm{Mg}$ prepared by extrusion of milled powder at 4 different temperatures were successfully created. It was investigated that higher extrusion temperature resulted in a structure with large deformed grains, while lower extrusion temperature exerted fine-grained structures. Large grains probably combined with texture caused anisotropy of mechanical properties of products extruded at $400^{\circ} \mathrm{C}$ and $500^{\circ} \mathrm{C}$. Higher extrusion temperature led to the greater TYS and UTS, however, at the cost of lower elongation. Materials extruded at higher temperatures exerted higher UTS than materials extruded at 200 or $300{ }^{\circ} \mathrm{C}$ due to the possible hardening. Extrusion temperature of $300{ }^{\circ} \mathrm{C}$ seems to exert a balance between dynamic hardening and softening processes. Therefore, it is characterised with the best combination of mechanical properties out of the tested materials. The corrosion rate of all materials was negatively affected by the iron inclusions. Nevertheless, materials extruded at lower temperature exerted lower corrosion rate due to the smaller grain size.

\section{Acknowledgment}

Authors wish to thank the specific university research A1_FCHT_2020_003 for the financial support of this research.

\section{References}

[1] LIU, C., LU, S., FU, Y., ZHANG, H. (2015). Flammability and the oxidation kinetics of the magnesium alloys AZ31, WE43, and ZE10. In: Corrosion Science, Vol. 100, No., pp. 177-185.

[2] SHIH, T.-S., LIU, J.-B., WEI, P.-S. (2007). Oxide films on magnesium and magnesium alloys. In: Materials Chemistry and Physics, Vol. 104, No. 2, pp. 497-504. magnesium alloys as biodegradable materials.
[3] GU, X.-N., ZHENG, Y.-F. (2010). A review on
This is due to the disruption of the oxides on the surface of the powder during milling. Therefore, the specific microstructure with a continuous network of oxides, which greatly deteriorate corrosion properties is not present in the sample $[22,23]$. Moreover, the same trend that the corrosion rate increases with increasing extrusion temperature was observed. This is associated with a finer structure which improves corrosion resistance. Measured corrosion rates are still better than an as-cast ingot of $\mathrm{Mg}\left(9 \mathrm{~mm} \cdot \mathrm{a}^{-1}\right)$ [24].

Ex $400{ }^{\circ} \mathrm{C}$

Ex $500{ }^{\circ} \mathbf{C}$

$5.8 \pm 0.2$

$6.0 \pm 0.3$

In: Frontiers of Materials Science in China, Vol. 4, No. 2, pp. 111-115.

[4] STAIGER, M. P., PIETAK, A. M., HUADMAI, J., DIAS, G. (2006). Magnesium and its alloys as orthopedic biomaterials: a review. In: Biomaterials, Vol. 27, No. 9, pp. 172834.

[5] AHMADKHANIHA, D., JÄRVENPÄÄ, A., JASKARI, M., SOHI, M. H., ZAREIHANZAKI, A., FEDEL, M., DEFLORIAN, F., KARJALAINEN, L. P. (2016). Microstructural modification of pure $\mathrm{Mg}$ for improving mechanical and biocorrosion properties. In: Journal of the Mechanical Behavior of Biomedical Materials, Vol. 61, No., pp. 360-370.

[6] KUBÁSEK, J., DVORSKÝ, D., ČAVOJSKÝ, M., VOJTECH, D., BERONSKÁ, N., FOUSOVÁ, M. (2017). Superior Properties of Mg-4Y-3RE-Zr Alloy Prepared by Powder Metallurgy. In: Journal of Materials Science \& Technology, Vol. 33, No. 7, pp. 652-660.

[7] RALSTON, K. D., BIRBILIS, N., DAVIES, C. H. J. (2010). Revealing the relationship between grain size and corrosion rate of metals. In: Scripta Materialia, Vol. 63, No. 12, pp. 12011204.

[8] DVORSKY, D., KUBASEK, J., VOJTECH, D., CAVOJSKY, M. (2016). Structure and mechanical properties of WE43 prepared by powder metallurgy route. In: Manufacturing Technology, Vol. 16, No. 5, pp. 896-902.

[9] HWANG, S., NISHIMURA, C., MCCORMICK, P. G. (2001). Mechanical milling of magnesium powder. In: Materials Science and Engineering: A, Vol. 318, No. 1, pp. 22-33.

[10] DVORSKÝ, D., KUBÁSEK, J., VOJTĚCH, D., VOŇAVKOVÁ, I., VESELÝ, M., 
ČAVOJSKÝ, M. (2017). Structure and mechanical characterization of $\mathrm{Mg}-\mathrm{Nd}-\mathrm{Zn}$ alloys prepared by different processes. In: IOP Conference Series: Materials Science and Engineering, Vol. 179, No. 1, pp. 012018.

[11] DVORSKÝ, D., KUBÁSEK, J., VOJTECH, D., VAVRÍK, J., Microstructure and mechanical properties of extruded $\mathrm{Mg}-2 \mathrm{Y}-1 \mathrm{Zn}$ magnesium alloy. In METAL 2017 - 26th International Conference on Metallurgy and Materials, Conference Proceedings, 2017; Vol. 2017-January, pp 15191523.

[12] KARASOGLU, M., KARAOGLU, S., ARSLAN, G. (2019). Mechanical properties of Mg-based materials fabricated by mechanical milling and spark plasma sintering. In: Proceedings of the Institution of Mechanical Engineers, Part L: Journal of Materials: Design and Applications, Vol. 233, No. 10, pp. 1972-1984.

[13] KUBASEK, J., VOJTĚCH, D., DVORSKY, D. (2015). Preparation and properties of composite materials with magnesium matrix and Hydroxyapatite reinforcement. In: Manufacturing Technology, Vol. 15, No. 4, pp. 562-567.

[14] ČAVOJSKÝ, M., TREMBOSOVA, V., BERONSKÁ, N., NAGY, S., NOSKO, M. (2019). Microstructure and mechanical properties of extruded profiles made from pure magnesium powders. In: Metallic Materials, Vol. 57, No., pp. 371-376.

[15] PÉREZ, P., GARCÉS, G., ADEVA, P. (2007). Influence of texture on the mechanical properties of commercially pure magnesium prepared by powder metallurgy. In: Journal of Materials Science, Vol. 42, No. 11, pp. 3969-3976.

[16] AL-SAMMAN, T., GOTTSTEIN, G. (2008). Dynamic recrystallization during high temperature deformation of magnesium. In: Materials Science and Engineering: A, Vol. 490, No. 1, pp. 411-420.

[17] BARNETT, M. R., SULLIVAN, A., STANFORD, N., ROSS, N., BEER, A. (2010).
Texture selection mechanisms in uniaxially extruded magnesium alloys. In: Scripta Materialia, Vol. 63, No. 7, pp. 721-724.

[18] ELSAYED, A., UMEDA, J., KONDOH, K. (2011). The texture and anisotropy of hot extruded magnesium alloys fabricated via rapid solidification powder metallurgy. In: Materials \& Design, Vol. 32, No. 8, pp. 4590-4597.

[19] STANFORD, N., BARNETT, M. (2008). Effect of composition on the texture and deformation behaviour of wrought $\mathrm{Mg}$ alloys. In: Scripta Materialia, Vol. 58, No. 3, pp. 179-182.

[20] LEI, W., ZHU, D., WANG, H., LIANG, W. (2019). Microstructure and Mechanical Properties of Pure Magnesium Subjected to Hot Extrusion. In: Journal of Wuban University of Technology-Mater. Sci. Ed., Vol. 34, No. 5, pp. 11931196.

[21] KUBÁSEK, J., VOJTĚCH, D., DVORSKỲ, D. (2017). The effect of thermo-mechanical processing on the structure, static mechanical properties and fatigue behaviour of pure $\mathrm{Mg}$. In: Materiali in tehnologije, Vol. 51, No. 2, pp. 289296.

[22] DVORSKY, D., KUBASEK, J., VOJTECH, D. (2018). A new approach in the preparation of biodegradable $\mathrm{Mg}-\mathrm{MgF} 2$ composites with tailored corrosion and mechanical properties by powder metallurgy. In: Materials Letters, Vol. 227, No., pp. 78-81.

[23] DVORSKÝ, D., KUBÁSEK, J., VOJTĚCH, D. (2019). Magnesium composite materials prepared by extrusion of chemically treated powders. In: Manufacturing Technology, Vol. 19, No. 5, pp. $740-744$.

[24] LI, N., GUO, C., WU, Y. H., ZHENG, Y. F., RUAN, L. Q. (2012). Comparative study on corrosion behaviour of pure $\mathrm{Mg}$ and WE43 alloy in static, stirring and flowing Hank's solution. In: Corrosion Engineering, Science and Technology, Vol. 47, No. 5, pp. 346-351. 